\title{
DISINFORMASI KEAGAMAAN DI INDONESIA: TINJAUAN WACANA
}

\section{RELIGIOUS DISINFORMATION IN INDONESIA: A DISCOURSE APPROACH}

\author{
Ubaidillah, Arief Hartanto \\ Pusat Penelitian Masyarakat dan Budaya \\ e-mail:23ubaid@gmail.com,riefhartanto@gmail.com
}

\begin{abstract}
This paper attempts to describe the disinformation on communism, the People Republic of China, and Chinese Indonesians that show the correlation between ethnicity and religious sentiments, especially Islam intertwined with historical narratives from the early days of the establishment of the Republic of Indonesia. The interwoven narratives were used to describe a projection of disinformation impact desired by the disinformation actors. Data on religious disinformation discourse was obtained from the cekfakta.com and turnbackhoax.id managed by the Indonesian Anti-Defamation Society (Mafindo). The site confirmed whether or not the information is classified as disinformation. The data were analyzed using the theoretical foundation of critical discourse analysis proposed by Fairclough (1989; 1992; 1995) and speech acts developed by Austin (1968) and Searle (1969). Islamic religious disinformation in Indonesia may have a high degree of persuasion since it has a historical foundation, the underlying narrative is maintained by authoritative actors, and is supported by economic inequality conditions among groups of people associated with aspects of religion and ethnicity. This persuasion power can ignite the mental state of the recipient of disinformation dominated by anger, hatred, or revenge in interpreting a discourse. This disinformation can also change the demographic resource potentials into political resources because it is able to reach the majority of Indonesia population. The incident of Chinese worship houses burning in Tanjung Balai shows that the religious disinformation also brings about a potency to escalate into riots or conflicts among groups of people.
\end{abstract}

Keywords: Religious Disinformation, Historical Narratives, Directive Principle, Discourse Approach

\section{ABSTRAK}

Artikel ini berupaya untuk memaparkan disinformasi bertema komunisme negara China dan etnis China yang menunjukkan kelindan antara sentimen etnisitas dan agama, khususnya agama Islam yang berjalinan dengan narasi-narasi historis dari masa-masa awal terbentuknya Republik Indonesia. Jalinan narasi-narasi tersebut digunakan untuk mendeskripsikan proyeksi dampak disinformasi yang diinginkan oleh pelaku disinformasi. Data wacana disinformasi keagamaan diperoleh dari situs cekfakta.com dan turnbackhoax.id yang dikelola Masyarakat Anti Fitnah Indonesia (Mafindo). Situs tersebut melakukan konfirmasi apakah suatu informasi tergolong disinformasi atau bukan. Data dianalisis dengan menggunakan landasan teori analisis wacana kritis Fairclough (1989; 1992; 1995), tindak tutur Austin (1968), dan Searle (1969). Disinformasi keagamaan Islam di Indonesia mungkin memiliki daya persuasi tinggi karena memiliki landasan historis, dirawat oleh aktor otoritatif, dan ditopang oleh kondisi ketimpangan ekonomi antarkelompok masyarakat yang diasosiasikan secara aspek keagamaaan dan etnisitas. Daya persuasi ini dapat memantik keadaan mental penerima disinformasi terdominasi oleh kemarahan, kebencian, atau hasrat membalas dendam dalam menginterpretasi sebuah wacana. Disinformasi ini pula dapat mengubah potensi sumber daya demografi menjadi sumber daya politik karena mampu menjangkau mayoritas penduduk Indonesia. Peristiwa Tanjung Balai memperlihatkan bahwa disinformasi ini pun sangat berpotensi menjadi kerusuhan atau konflik antarkelompok masyarakat.

Kata Kunci: Disinformasi Agama, Prinsip Direktif, Pendekatan Wacana

\section{LATAR BELAKANG}

Disinformasi dapat memberikan efek yang berbahaya dan merusak. Contohnya adalah peristiwa pembakaran klenteng dan wihara di Tanjung Balai, Sumatera Utara pada tahun 2016 yang terjadi karena merebaknya disinformasi tentang seorang Tionghoa atau Cina yang melarang azan dan mematikan pengeras suara masjid (Komnas, 2016). Massa umat Islam mengarahkan pelampiasan rasa 
ketersinggungan akibat agamanya direndahkan, dihina, dan disepelekan terhadap tempat ibadah yang dianggap sebagai representasi agama yang dianut oleh orang Tionghoa. Kasus yang semula merupakan perkara individual antara Meliana dengan tetangganya mengenai volume pengeras suara masjid menjadi perkara komunal antarkelompok masyarakat, yakni kelompok umat Islam dengan etnis Tionghoa.

Agama sebagaimana identitas pada umumnya memiliki dua sisi, yakni sisi internal yang memberikan harga diri pada pemeluknya, dan sisi eksternal yang menghubungkan orang dengan orang dalam satu himpunan (Fukuyama, 2018 dan Moon, 2018). Terlebih, perasaan harga diri dari beragama dianggap bersumber dari Tuhan sehingga bersifat mutlak. Penodaan terhadap identitas agama dianggap sama halnya menghina Tuhan. Oleh karena itu, rasa ketersinggungan dan kebencian akibat penodaan identitas (agama) dapat menjadi motivasi seseorang untuk bertindak meneguhkan rekognisi terhadap identitas yang disandangnya. Tidak heran, rasa ketersinggungan dan kebencian tersebut sengaja direkayasa untuk kepentingan politik tertentu (George, 2017 dan Fukuyama, 2018), misal politisi menampilkan diri sebagai pihak yang mampu memulihkan kembali harga diri yang terluka saat masa pemilihan umum sehingga massa memberikan suara kepadanya. Laporan Wahid Institue (2017) telah mengonfirmasi pendapat teoretis tersebut dengan memaparkan bahwa pada kontestasi pemilihan kepala daerah DKI Jakarta, Jawa Barat, dan Banten pada 2016 lalu, agama dipolitisasi untuk kepentingan elektoral.

Politik kebencian (Fukuyama, 2018) atau pelintiran agama (Cherian, 2017) dapat berwujud disinformasi menggunakan sentimen identitas seperti agama atau etnisitas. Terlebih, untuk konteks Indonesia, menurut survei PEW Research Center (2018), 93\% masyarakat Indonesia menyatakan agama adalah bagian penting dalam menentukan keputusan hidup mereka. Oleh karena itu, disinformasi tidak dapat dilepaskan dari konteks perjuangan perebutan kekuasaan, baik dalam pengertian formal maupun kultural, bahkan menjadi penanda diskursif perjuangan tersebut (Farkas \& Schou, 2018). Nadzir, Seftiani, dan Permana (2019) pun memaparkan bahwa ada kecenderungan disinformasi mengenai China dan kebangkitan Partai Komunis Indonesia (PKI) dipercayai oleh masyarakat. Misalnya, disinformasi mengenai kehadiran tenaga kerja asing di Indonesia lebih dipercayai oleh masyarakat urban, sedangkan masyarakat pedesaan lebih memercayai ihwal kebangkitan PKI di bawah kepemimpinan Presiden Joko Widodo (Jokowi). Kedua disinformasi tersebut mewarnai masa kampanye pemilihan presiden Indonesia 2019.

Temby dan $\mathrm{Hu}$ (2020) pada artikelnya memberikan dua catatan penutup bahwa kelompok Islam menghubungkan virus corona dengan dugaan pelangaran hak asasi manusia muslim Uighur serta teori konspirasi yang diarahkan kepada Negara China berimplikasi terhadap etnis cina di Indonesia. Tembi dan $\mathrm{Hu}$ tidak menjelaskan lebih jauh mengenai pernyataan itu. Padahal, sebagai penutup sebuah artikel, pernyataan itu memiliki bentang konseptual dan pembuktian dengan bahasan utama artikel mengenai perbincangan di Twitter dan Facebook serta pemberitaan di media daring. Hasil analisis mengenai dua jenis data tersebut lebih menjelaskan mengenai panic buying yang terjadi serta berkembangnya narasi bahwa virus corona adalah senjata biologis yang terkait dengan perang dagang China dan Amerika Serikat.

Artikel ini, pada tahap tertentu, menindaklanjuti tesis yang diajukan oleh Tembi dan $\mathrm{Hu}$. Artikel tersebut mengeksplorasi proses sejarah politik yang menimbulkan/memunculkan sentimen terhadap China dapat berimplikasi terhadap etnis China untuk menjawab mengapa kelompok Islam di Indonesia menarasikan sentimen dan menunjukkan poros narasi yang berpangkal pada antikomunisme. Dengan dipahaminya proses sejarah tersebut, dapat terlihat bahwa variasi tematik disinformasi mengenai China dapat mengikuti peristiwa yang tengah marak, namun relasi konfliktual yang tergambar masih melibatkan aktor-aktor yang sama. Oleh karena itu, artikel ini tidak menganggap bahwa semua tema disinformasi memiliki potensi destruktif dan koersif yang sama. Proses sejarah yang dilalui masyarakat membuat suatu tema yang 
mengandung keajegan antagonisme menjadi lebih berpotensi. Hal demikian berbeda dengan artikel Ulya (2018) yang secara implisit mengasumsikan bahwa semua hoax mempengaruhi religiusitas masyarakat. Keberagamaan masyarakat yang didasari oleh hoax disebut membahayakan, mengotak-ngotakkan masyarakat, mengintensifkan ketegangan, dan membuahkan tindakan kekerasan. Dengan membahas exisiting narratives, artikel ini berupaya menjelaskan bahwa hoax atau disinformasi yang dapat memberikan dampak yang disebutkan Ulya tersebut adalah disinformasi yang memiliki dasar historis dalam menyajikan antagonisme.

Artikel ini berupaya memaparkan disinformasi bertema komunisme negara China ${ }^{1}$ dan etnis Cina $^{2}$ yang menunjukkan kelindan antara sentimen etnisitas dan agama, khususnya agama Islam yang berjalinan dengan narasinarasi historis dari masa-masa awal terbentuknya Republik Indonesia. Jalinan narasi-narasi tersebut digunakan untuk mendeskripsikan proyeksi dampak disinformasi yang diinginkan oleh pelaku disinformasi. Data wacana disinformasi keagamaan diperoleh dari situs cekfakta.com dan turnbackhoax.id yang dikelola Masyarakat Anti Fitnah Indonesia (Mafindo). Situs tersebut melakukan konfirmasi apakah suatu informasi tergolong disinformasi atau bukan.

\section{PRINSIP DIREKTIF DISINFORMASI}

Menurut Unesco (2019), disinformasi adalah informasi yang salah atau palsu, tetapi orang yang menyebarkan atau membuat informasi mengetahui kesalahan tersebut dan tetap menyebarkannya sebagai kebenaran. Definisi ini hanya memuat aspek pelaku disinformasi yang mengetahui nilai suatu informasi dan memanipulasi nilai tersebut. Definisi tersebut tidak memasukan aspek penerima disinformasi, padahal manipulasi nilai

1 Artikel ini menggunakan China untuk merujuk kepada negara China atau Republik Rakyat Tiongkok

2 Artikel ini menggunakan kata Cina untuk merujuk etnis Cina atau Tionghoa di Indonesia. Istilah-istilah ini digolongkan bersinonim dalam Kamus Besar Bahasa Indonesia. Pembedaan China dan Cina dilakukan hanya untuk mencegah kebingungan rujukan karena frekuensi keberulangan kedua kata ini tinggi. tersebut ditujukan agar dipercayai oleh penerima dan penerima menentukan keputusan hidup berdasarkan informasi yang salah tersebut. Untuk melengkapi definisi yang dibuat oleh Unesco tersebut, paparan Cherian George mengenai "pelintiran kebencian" (hatespin) dapat dipertimbangkan. Menurut George (2017) pelintiran kebencian adalah penghinaan dan rasa ketersinggungan yang sengaja diciptakan sebagai strategi politik untuk mengeksploitasi identitas kelompok, memobilisasi pendukung, dan menekan lawan. Meski George tidak membahas mengenai disinformasi, namun konsep pelintiran kebencian yang ditawarkannya mampu menjawab tujuan manipulasi nilai salah suatu informasi menjadi benar, yakni untuk memberikan keuntungan bagi pelaku disinformasi dengan memanfaatkan sisi emosional penerima disinformasi.

Dari elaborasi definisi di atas, dapat disimpulkan bahwa disinformasi adalah pelintiran kebencian, ketakutan, atau ketersinggungan (primordial) yang terkalkulasi untuk menipu kesadaran seseorang sehingga bertindak koersif terhadap seseorang atau kelompok yang dibenci dan atau tindakan yang diproyeksikan oleh pelaku disinformasi. Pengertian ini menegaskan keberadaan agensi, intensi, sekaligus proyeksi dari tindakan disinformasi. Ketiga faktor ini menggambarkan perbedaan disinformasi dengan misinformasi yang merupakan tindakan yang dihasilkan dari salah-kenal terhadap nilai suatu informasi. Selain itu, ketiga unsur tersebut menegaskan bahwa disinformasi bukan tindakan arbitrer, melainkan sebuah tindakan yang dikonstruksikan untuk melayani sebuah fungsi. Ketiga faktor tersebut pun hadir secara implisit dalam definisi disinformasi menurut Komisi Uni Eropa (2018) yang menyebutkan bahwa disinformasi adalah segala bentuk kepalsuan, ketidaktepatan, dan penyimpangan informasi yang didesain, disajikan, dan disebarkan untuk secara sengaja menyebabkan kerusakan atau untuk keuntungan tertentu. Dalam pemikiran demikian, disinformasi dapat dianggap sebagai sebuah stimulan yang mampu menghasilkan reaksi tertentu yang terprediksi. 
Disinformasi sebagai salah satu jenis interaksi bercorak massal ditinjau dari salurannya, seperti media sosial atau ruang internet secara umum. Identifikasi terhadap fitur tekstual dapat digunakan untuk menelusuri partisipan yang dilibatkan dalam wacana (Martin, 2010) karena teks adalah bentuk dari interaksi sosial (Halliday, 1978). Fitur linguistis dari teks sebenarnya adalah unsur indrawi dari wacana yang menjadi bahan utama interpretasi penerima mengingat pola komunikasi di ruang digital yang bercorak dimediasi oleh teks. Oleh karena itu, upaya manipulasi nilai salah dari informasi menjadi benar mesti diwujudkan dalam bentuk teks agar mampu dijangkau penerima dan diarahkan pada aspek konstekstual tertentu. Aspek konstekstual yang telah disimulasi tersebut menunjukkan proyeksi tindakan atau keadaan masa depan dari penerima pascainterpretasi wacana disinformasi.

Tulisan ini memadukan pendekatan analisis wacana kritis yang menganalisis wacana dalam tiga dimensi: dimensi teks, dimensi praktik kewacanaan, dan dimensi sosial budaya (Fairclough, 1989; 1992; 1995) dan teori tindak tutur. Titik temu kedua teori adalah kesamaan ontologis yang mendefinisikan penggunaan bahasa sebagai tindakan untuk mengubah dunia. Austin (1968) membuat konsepsi tindakan yang semula sekadar bernilai fisik dan memasukan nilai verbal dalam tindakan. Tindakan menikah dapat dijadikan sebagai contoh karena tindakan ini dilakukan menggunakan bahasa, namun mengubah relasi kedua orang menjadi suami-istri. Konsepsi Austin ini dijabarkan oleh Searle (1969) dalam klasifikasi tindakan dengan bahasa atau lazim disebut tindak tutur yang dapat berwujud tindak tutur asertif, direktif, ekspresif, komisif, dan deklaratif. Klasifikasi tersebut berdasarkan kriteria maksud ilokusi (illocution point), arah pencocokan (direction of fit), dan keadaan psikologis (psycological state) penutur (Searle, 1979). Ditinjau dari maksud ilokusinya, wacana disinformasi mengandung unsur upaya pelaku dalam mengubah dunia dengan kata-kata atau arah pencocokannya adalah dunia yang menyesuaikan dengan kata (world to word). Oleh karena itu, wacana disinformasi dapat digolongkan sebagai tindak tutur direktif yang merupakan ekspresi keinginan pelaku agar tindakan yang diproyeksikan dalam wacana dilakukan oleh penerima.

Peristiwa pembakaran wihara dan klenteng di Tanjung Balai dapat dijadikan ilustrasi untuk menerangkan konsepsi teoretik di atas. Transformasi Meliana menjadi seorang Tionghoa atau Cina adalah bagian tekstual penting untuk memastikan transfer ideasional 'pelarangan azan dan mematikan pengeras suara' sampai kepada mitra tutur. Atribusi Meliana yang disembunyikan dan digantikan dengan Tionghoa atau Cina adalah cara lingual untuk memelintir prasangka kebencian atau konfliktual antara umat Islam dengan warga keturunan Cina atau Tionghoa. Prasangka kebencian ini sudah diketahui oleh pelaku dan disimulasikan mampu membuat penerima wacana disinformasi yang menganut agama Islam dapat bertindak lebih dari sekadar membalas Meliana, yakni membalas perlakuan orang Tionghoa atau Cina secara umum. Oleh karena itu, sasaran perusakan adalah bangunan yang dianggap melambangkan komunitas Cina, yaitu wihara dan klenteng.

\section{ANTAGONISME KOMUNISME DAN ISLAM SEBAGAI EXISTING NARRATIVES}

Disinformasi balutan sentimen keagamaan tidak dilakukan di ruang yang hampa. Sebagaimana disebutkan di atas, topik disinformasi berkembang seiring waktu, tetapi jalinan partisipan dalam antagonisme mengikuti narasi-narasi yang telah ada. Tulisan ini berfokus pada disinformasi yang menampilkan relasi antagonisme Islam dengan Cina yang terbangun secara historis. Penelusuran historis ini menjadi konteks sosial budaya yang menjadi dimensi terluar dari teks dalam analisis wacana kritis. Peristiwa-peristiwa historis yang disosialisasikan dalam ruang-ruang kultural, seperti keluarga, pendidikan formal, atau bahkan humor memengaruhi proses interpretasi teks.

Terma Cina sendiri memiliki ambigiutas pengertian karena dapat merujuk kepada entitas negara Republik Rakyat China/Tiongkok atau entitas etnis yang hidup di Indonesia yang 


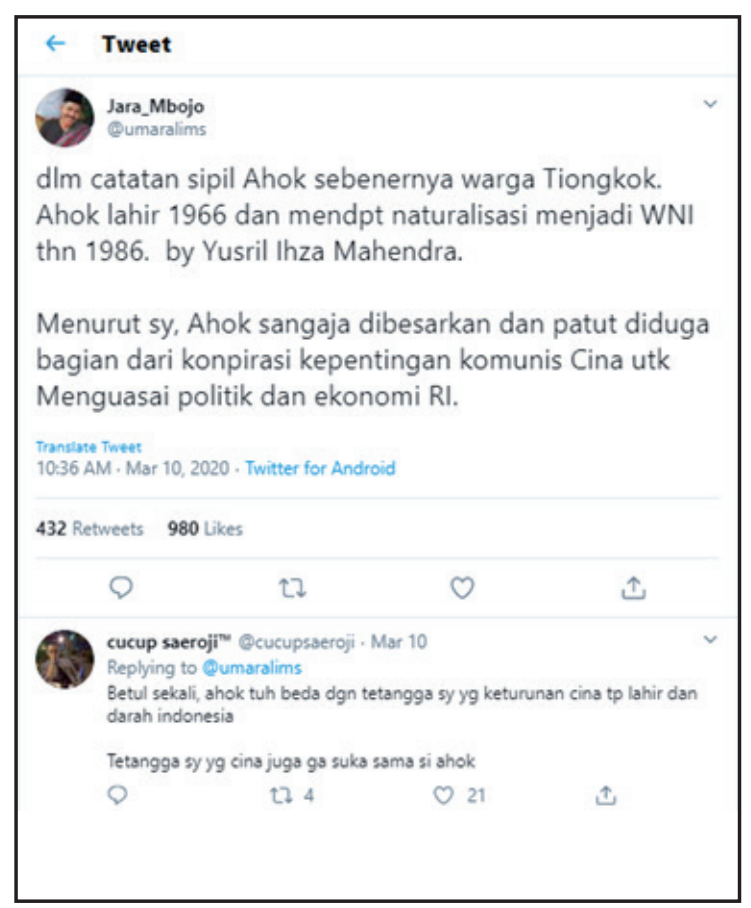

Gambar 1 Ambiguitas Cina dalam Konteks Politik Ahok

lazim disebut pula dengan Tionghoa atau Peranakan. Ambigiutas pengertian Cina ini justru dimanfaatkan untuk menampilkan relasi keduanya terjalin secara konspiratif. Sebagai misal, pada momen pemilihan kepala daerah DKI Jakarta 2017 lalu, Basoeki Tjahja Purnama atau Ahok yang menjadi salah satu kandidat dinarasikan sebagai agen (Partai) Komunis China yang akan menguasai ekonomi dan politik Indonesia seperti yang ditampilkan dalam Gambar 1. Narasi ini dibentuk dengan memanfaatkan realitas Ahok sebagai etnis Cina atau Tionghoa yang hidup di Indonesia.

Narasi konspiratif demikian pun mengiringi perjalanan karir politik Jokowi semenjak menjadi Gubernur DKI Jakarta pada 2012 sampai menjadi Presiden Indonesia pada 2019 untuk kedua kalinya. Jokowi digambarkan menyembunyikan asal-usul keluarganya yang beretnis Cina sebagai siasat untuk menutupi tujuannya menjadi presiden Indonesia, yaitu mengubah Indonesia menjadi negara komunis yang anti-Islam dan berkiblat ke Republik Rakyat China sebagaimana dinarasikan dalam Gambar 2 di bawah ini.

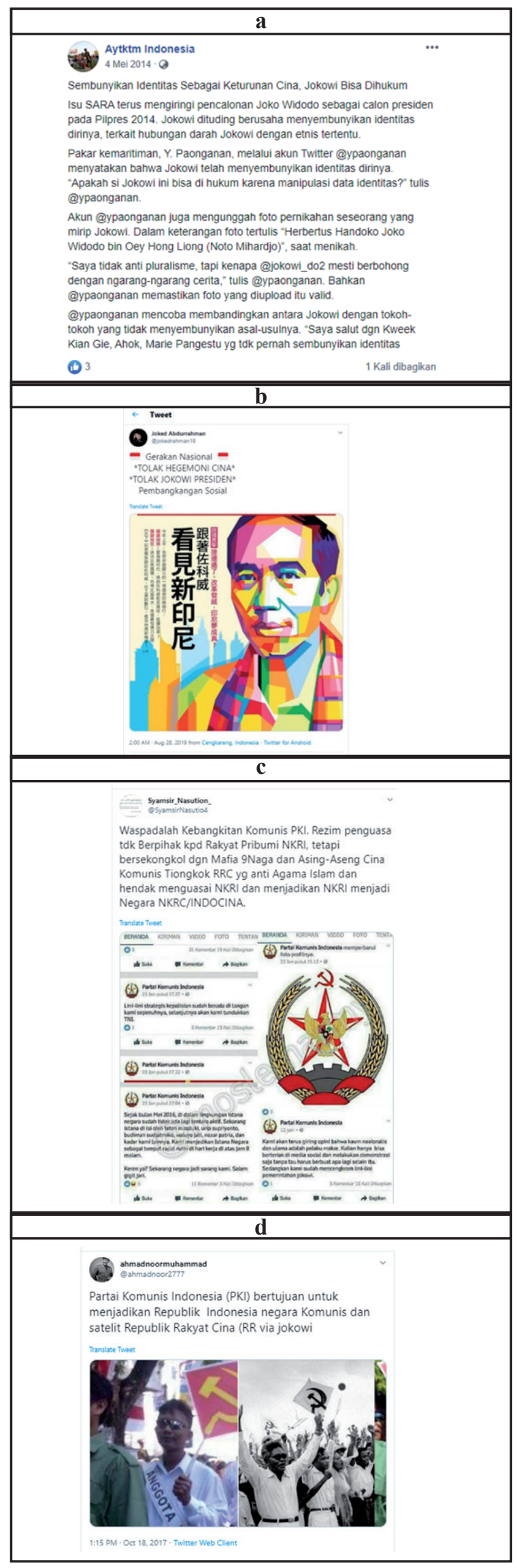

Gambar 2 Narasi Konspiratif Mengenai Presiden Joko Widoo dan Komunisme 


\begin{tabular}{l}
\hline Tweet \\
Komunishah Nusaybah \\
kami. \\
Komunis adalah faham anti agama. \\
Komunis anti trhdp asas ketuhanan. \\
Komunis bnyk mengekang hak asasi manusia. \\
Knp bukan komunis yg kalian takutkan? \\
\#PrabowoBentengNKRI \\
\#PrabowoMenangDebat
\end{tabular}

Gambar 3: Narasi Media Sosial yang Menggambarkan Antagonisme Islam dan Komunisme

Penelusuran sejarah penting dilakukan untuk memahami lebih dalam mengenai antagonisme Cina dengan Islam sehingga narasi demikian dipercaya oleh sebagian kelompok masyarakat Indonesia. Meski sejarah ketimpangan antara etnis Cina dan 'pribumi' dapat ditelusuri sejak masa kolonial, tetapi tulisan ini bertitik tolak pada peristiwa pemberontakan simpatisan PKI di bawah pimpinan Musso di Madiun tahun 1949 yang disebut oleh Katharine Mcgregor (2009) memperkuat antagonisme PKI dan kelompok Islam. Relasi antagonisme tersebut dalam perjalanan sejarah politik Indonesia terkelindan dengan etnis Cina dan negara Republik Rakyat China pascaperistiwa 1965. Pembatasan titik tolak peristiwa sejarah ini disebabkan oleh kesenambungan narasi tentang peristiwa 1948 dengan peristiwa 1965 yang membentuk narasi 'komunis membantai ulama' dalam kontestasi elektoral 2019, seperti yang terdapat dalam Gambar 3.

Penggunaan narasi antagonis PKI dan umat Islam tidak hanya terjadi di Indonesia pascareformasi. Pada pemilihan umum Indonesia pertama tahun 1955, Partai Masyumi menggunakan isu pembantaian ulama pada 1948 dalam narasi kampanyenya untuk menyudutkan PKI yang juga menjadi peserta pemilu tersebut (Mcgregor, 2009). Demikian pula, pada masa awal penumpasan PKI pasca-65, masyarakat digerakkan untuk menumpas simpatisan komunis karena dianggap akan melakukan hal yang sama seperti yang PKI lakukan pada 1948.
Nahdatul Ulama (NU) sebagai organisasi Islam di Indonesia yang memiliki simpatisan sampai tingkat akar dapat menjadi representasi aktor yang terlibat dalam antagonisme ini. Rangkaian konflik NU melawan komunisme, menurut buku Benturan NU-PKI 1948-1965 yang kerap disebut Buku Putih NU-PKI, telah terjadi sejak tahun 1947 dan terus berkelanjutan hingga tahun 1948, lalu berlanjut lagi pada tahun 1950-an, dan puncaknya adalah pertengahan tahun 1960an (Tim PBNU, 2013). Kedua kelompok bertikai dan bertempur untuk memperebutkan tanah yang diklaim PKI dan membalas PKI yang menghina agama dan Tuhan. Antagonisme ini mengalami puncaknya pada peristiwa 1965.

Peristiwa pemberontakan PKI tahun 1965 itu menjadi trauma besar bagi umat Islam. Sebab, kalau tidak ada langkah dan gerak cepat sudah dibayangkan Indonesia akan menjadi negara komunis, apalagi jumlah anggota PKI saat itu menurut Ketua BPI Subandrio sudah mencapai 20 juta. Dengan berdirinya Negara Komunis Indonesia dibayangkan akan terjadi banjir darah. Islam akan sirna dan Republik Indonesia berdasarkan Pancasila. Islam hanya dalam sejarah masa lalu. Dengan perkiraan semacam itu lalu umat Islam menjadi waspada, kemudian melakukan balasan terhadap serangan yang dilakukan PKI. Bahkan ketika PKI melakukan pemberontakan umat Islam dalam hal ini NU dengan Ansor dan Banser-nya melakukan langkah penyelamatan rakyat, agama, dan negara dengan menumpas PKI (Tim PBNU, 2013).

Konflik antara Islam dengan komunisme disebabkan oleh tiga faktor, yakni (i) perbedaan epistemologi dan ideologi mengenai kehidupan terutama dalam kaitannya dengan keyakinan terhadap eksistensi entitas transedental, (ii) perbedaan kultur religius yang mendasari eksistensi Islam dengan sekulerisme yang diusung komunisme, dan (iii) pola politik PKI yang konfrontatif bertentangan dengan politik Islam yang mengedepankan harmoni dalam pemenuhan kesejahteraan umat (Tim PBNU, 2013).

Narasi penumpasan PKI menjadi tulang punggung yang menyanggah roda pemerintahan Orde Baru. Dalam sosialisasi komunis sebagai bahaya laten bagi bangsa Indonesia, Pancasila ditampilkan sebagai negasi dari komunisme 
yang terbukti merusak bangsa Indonesia dan pemerintahan Orde Pancasila adalah agen tunggal penegak Pancasila di Indonesia. Pihak yang tidak sejalan dengan agenda pancasila Orde Baru dianggap sebagai bagian dari komunis. Kebijakan-kebijakan politik antikomunisme Orde Baru yang menyebabkan sentimen antagonisme terhadap komunisme merembet kepada etnis Cina di Indonesia.

Kebijakan penumpasan PKI sampai ke akar-akarnya pada masa Orde Baru salah satunya terwujud dalam bentuk pelarangan demonstrasi kebudayaan etnis Cina di Indonesia. Dalam posisi masih sebagai Pejabat Presiden Republik Indonesia, Soeharto menertibkan Instruksi Presiden Republik Indonesia nomor 14 tahun 1967 yang melarang demonstransi kebudayaan etnis Cina di ruang publik karena dianggap berasosiasi dengan negara leluhur etnis Cina yang berasal dari China dan demonstrasi ini dapat menimbulkan pengaruh psikologis, mental, dan moril yang kurang wajar terhadap warga negara Indonesia. Kebijakan demikian membangun stigma komunisme di Indonesia yang dibawa, dirawat, dan dijalankan secara diam-diam oleh etnis Cina di Indonesia terkait dengan China sebagai negara yang dipimpin oleh Partai Komunis China. Terlebih, corak politik Orde Baru adalah desukarnoisasi dan kedudukan warga Tionghoa atau Cina menjadi kelompok yang disisihkan dan selalu dicurigai sebagai bagian dari rezim Soekarno yang pro komunisme (tionghoa. info).

Narasi 'komunis membantai ulama' yang terbangun sejak peristiwa 1948 sebagai pondasi historis membuat sentimen terhadap komunis bukan lagi sentimen ideologi, melainkan juga sentimen agama. Sentimen agama pun akhirnya memengaruhi relasi kelompok Islam dengan etnis Cina. Bara sentimen agama yang demikian mungkin terpercik oleh disinformasi 'seorang Tionghoa atau Cina melarang azan dan mematikan pengeras suara masjid', sehingga disinformasi tersebut dapat menyulut kemarahan massa.

Narasi tentang peristiwa-peristiwa historis telah menjadi struktur pengetahuan yang dimiliki seseorang dalam memorinya dan dapat dibangkitkan jika mendapat stimulus eksternal yang tepat. Stuktur pengetahuan tersebut lazim disebut skemata. Pembuat disinformasi dapat melakukan simulasi kognitif menggunakan skemata tersebut dalam proses konseptualisasi wacana sehingga teks mampu mengarahkan penerima bertindak sesuatu sesuai proyeksi pelaku. Simulasi tersebut menyusun probabilitas konteks-konteks yang dapat mengarahkan dan membatalkan proses interpretasi sesuai proyeksi pembuat teks. Pada akhirnya, proses simulasi akan menghasilkan fitur tekstual tertentu yang digunakan dalam teks.

Simulasi sebagaimana diuraikan di atas dapat diilustrasikan menggunakan contoh penggunaan kata sipit sebagai atribusi seseorang yang diberitakan Jawa Pos News Network (Gambar 7). Kata sipit telah menjadi bagian dalam skemata masyarakat Indonesia yang menandakan ciri fisik etnis Cina. Atribusi seorang wanita yang menolak ditilang atau dengan kata lain mendemonstrasikan diri sebagai individu yang berdiri di atas hukum sehingga merasa tidak layak dihukum dengan kata sipit secara simplisitis merelasikan tindakan tersebut lahir dari status etnisitas wanita tersebut. Atribusi sipit dilakukan karena secara simulatif mampu menopang proyeksi redaksi atas berita tersebut, yakni mampu menarik banyak orang untuk membaca berita tersebut karena rasa ketersinggungan atas tindakan yang didasari status etnisitas Cina. Atribusi rasial tersebut dapat dikatakan sebagai stimulan eksternal yang akhirnya membangkitkan sentimen agama terhadap etnis Cina. Dengan demikian tidak mengherankan abstraksi pembaca berita tersebut mampu memunculkan ciri lain yang dianggap dari entitas Cina, yakni beragama kristen (Gambar 4).

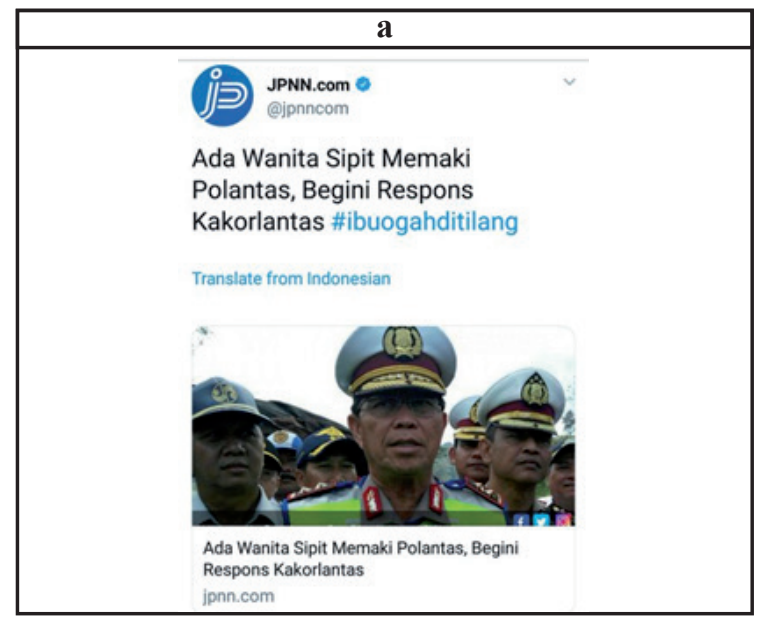




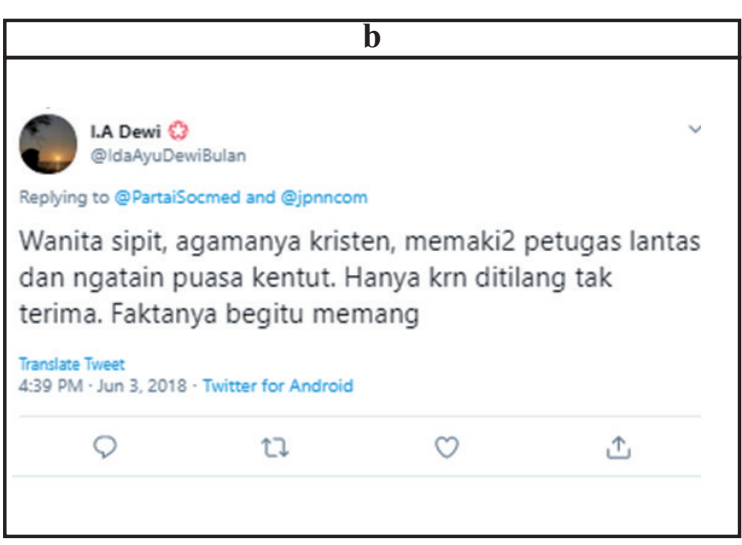

Gambar 4 Pemanfaatan Sentimen Antagonisme dalam Berita Media Daring

Pemberitaan yang dilakukan oleh $J P N N$ ini pun dapat dilihat sebagai upaya merawat dan memberdayakan sentimen terhadap etnis Cina. Antagonisme Islam dengan komunisme pun tergambar dalam ceramah-ceramah Abdul Somad, salah satu tokoh agama Islam yang menonjol di Indonesia masa kini, terutama dari kalangan umat Islam konservatif. Abdul Somad menyampaikan bahwa virus corona adalah tentara Allah yang dikirimkan untuk membalas perlakuan komunisme China terhadap umat Islam, terutama karena tindakan diskriminasi terhadap penduduk China di wilayah Uygur yang menganut agama Islam. Narasi yang dibangun Abdul Somad tidak lagi menempatkan Islam dan komunisme sebagai suatu keyakinan terhadap suatu entitas spritiual dan terhadap dunia, tetapi sudah merelasikannya secara antagonistik bahwa komunisme menzalimi Islam karena dalam pandangan komunisme, sudah ada bibit koersif terhadap agama yang anti terhadap Tuhan. Tindakan terhadap umat Islam di Uygur adalah salah satu bentuk tindakan koersif yang lahir dari keyakinan anti terhadap Tuhan.

... Maka ditolong Allah dengan berbagai macam tentara. Macam-macam Allah datang. Ada pula tentara yang terakhir ini bernama Corona. Orang berada di Uygur tak terkena virus ini. Banyak orang terheran-heran. Apa sebab? Salah satu sebabnya karena mereka berwudhu. Setiap hari mereka membasuh tangan. Virus tidak akan, virus tidak akan terkena kepada orang yang selalu menjaga kesucian. Mereka memakan binatang yang disembelih, yang dimasak, bukan yang mentah, bukan makan darah. Sebab di dalam darah ada bakterial penyakit. Mana kala ajaran Islam diamalkan. Pertolongan Allah SWT datang. Kalau kau tolong agama Allah. Allah akan menolongmu. Kalaulah bukan karena pertolongan Allah sudah lama Islam ini musnah dari atas muka bumi Allah. Mereka membuat tipu daya. Allah balas tipu daya mereka. Tipu daya Allah, pembalasan Allah lebih hebat daripada yang mereka lakukan (Tahfidz Media, 2019).

... datang lagi satu penguasa berkata 'kami yang paling banyak jumlahnya di atas dunia. Kami yang bisa menguasai alam semesta. Mana itu Tuhan. Mereka tak pernah mengenal Tuhan karena mereka adalah komunis, karena mereka ateis. Agama bertentangan dengan komunis. Agama bertentangan dengan keyakinan ateis. A tidak, TE Tuhan, IS keyakinan, ATEIS adalah keyakinan yang meyakini tidak ada Tuhan. Mana itu Tuhan'. Tidakkah kita melihat ucapan mereka sama seperti ucapan Fir'aun, yang keluar dari mulut mereka sama seperti yang keluar dari mulut Namruz. Mana kuasa Allah? Allah mengirimkan bakteri-bakteri kecil, kuasa itu pun roboh, hancur berkeping-keping (Redaksi Islam, 2019).

Relasi antagonis yang dibangun Abdul Somad dalam ceramahnya tersebut mungkin secara spesifik merujuk kepada China sebagai entitas negara. Namun, ambiguitas Cina sebagai etnis dan sebagai entitas negara tidak terfragmentasi secara tegas dan justru terkait kelindan secara konspiratif sebagaimana diuraikan di awal. Dengan demikian apa yang diarahkan kepada China, mengarah pula kepada Cina. Logika demikian yang dipakai oleh Pemerintah Orde Baru dalam pelarangan demonstrasi kebudayaan Cina di Indonesia yang dianggap terkait dengan penyebaran komunisme China.

Relasi antagonis Islam dan komunisme yang akhirnya merembes kepada etnis Cina terbentuk dalam rangkaian peristiwa dan keadaan yang kompleks. Keadaan ketimpangan ekonomi yang tajam di Indonesia memberi landasan persaingan kesejahteraan antara masyarakat Islam Indonesia dengan etnis Cina. Sejarah persaingan politik ideologi kelompok Islam dengan PKI menjadi spektrum persaingan kekuasaan dan perbedaan pandangan terhadap entitas spiritual sehingga membentuk kontestasi peneguhan kebenaran transedental. Ketiganya memuncak dan menciptakan kerusuhan Mei 1998 di beberapa kota di Indonesia yang menyasar etnis Cina sebagaimana temuan Tim Gabungan Pencari Fakta Kerusuhan Mei 1998. 


\section{BENTUK DISINFORMASI KEAGAMAAN}

Artikel ini mengambil judul disinformasi keagamaan meski yang dibahas pada bagian bentuk disinformasi ini secara tematik berkaitan dengan China. Hal demikian dilakukan karena artikel ini mengetengahkan bahwa disinformasi mengenai China ditujukan atau disajikan dalam bentuk (lingual) yang menautkan umat Islam dengan komunisme sebagai penghubung antagonisme. Antagonisme ini terbentuk dalam proses sejarah sejak awal kemerdekaan Indonesia, yaitu peristiwa Madiun yang terjadi pada 1948.

Bagian ini menyajikan analisis terhadap tiga disinformasi mengenai China. Disinformasi tersebut dianalisis menggunakan kerangka tiga dimensi analisis wacana kritis Norman Fairclough (1989; 1992; 1995). Bagian ini adalah analisis pada dimensi kedua dan pertama dalam analisis wacana kritis Fairclough, yaitu dimensi praktik kewacanaan dan dimensi teks. Dimensi teks adalah jalan masuk ke dimensi-dimensi lain, baik praktik kewacanaan maupun sosiokultural yang telah dibahas dalam analisis existing narratives. Analisis atas dimensi-dimensi ini dilakukan secara simultan. Oleh karena itu, deskripsi dalam bagian itu akan mempertautkan yang tampak dalam wacana dan praktik kewacanaan dengan dimensi sosiokultural. Secara unsur pembentuk, disinformasi di media sosial disusun dengan dua bahan baku utama, yaitu unsur figural, seperti gambar atau video dan teks. Unsur figural menjadi bukti gambaran dunia kepada penerima, sedangkan teks mendefinisikan gambaran dunia tersebut.

Wacana disinformasi berjudul "Mayat orang Cina bergelimpangan di jalan kota Wuhan" yang telah diverifikasi oleh turnbackhoax.id. Wacana ini diunggah pertama oleh akun Facebook "E-man syg" (facebook.com/rahman.abdullah.921) dan pengunggah kedua oleh Cacan Soemantri Agis (facebook.com/cacan.agis). Foto yang ditampilkan dalam unggahan bersumber dari Reuters (https://reut.rs/2SOvtTG) kemudian terdapat penambahan narasi yang tidak sesuai dengan konteks foto sebenarnya sehingga menimbulkan berita yang salah. Foto diberi keterangan demikian.
"Keterangan foto mayat-mayat orang China bergelimpangan di jalan-jalan kota Wuhan, China foto diambil dari Satelit. Azab untuk China Komunis. China menyiksa dan membunuh suku Uyghur. China menindas dan menyiksa ummat Islam di Xinjiang. China memutilasi tubuh manusia untuk diperjual belikan"

Secara intrinsik, pembentukan frasa China Komunis merupakan penggabungan entitas dunia yang berlainan kategori. China merupakan entitas negara, sedangkan Komunis adalah entitas ideologi. Oleh karena itu, frasa ini membentuk entitas tentang negara yang berideologi tertentu. Pembentukan ini sama halnya mengintrinsikan komunisme dalam diri China. Dalam penjabaran mengenai antagonisme Islam dan komunisme di bagian sebelumnya, disebutkan bahwa komunisme sudah memiliki unsur intrinsik koersif terhadap agama. Verba membunuh, menindas, menyiksa, dan memutilasi adalah ejawantah dari unsur intrinsik tersebut. Dengan kata lain, keterangan foto ini masih berada dalam spektrum antagonisme ini.

Tindakan-tindakan koersif tersebut yang menjadi dasar tugas menghukum China dengan virus corona yang mematikan. Interpretasi virus corona yang mematikan ini dihasilkan dengan memaknai kata Wuhan secara kontekstual. Kata Wuhan telah bermakna identik dengan virus corona karena Wuhan sebagai nama wilayah di Cina merupakan tempat virus itu pertama menyebar. Dengan mengatribusi Wuhan dengan azab yang terjalin secara kohesif melalui kesamaan penanda Cina, wacana ditransendenkan atau dengan kata lain, Tuhan dihadirkan dalam wacana. Kata $a z a b$ bersinonim dengan hukuman, namun dimensi kata $a z a b$ bersifat transenden atau tindakan yang hanya dilakukan oleh Tuhan. Secara deskriptif, $a z a b$ dapat dimengerti sebagai hukuman dari Tuhan. Secara metawacana (metadiscourse), kata $a z a b$ ini menunjukkan arah unggahan disinformatif ini, yakni ditujukan kepada umat Islam. Kata $a z a b$ sendiri merupakan kata yang diserap dari bahasa Arab dan berada dalam kelompok kata bidang keagamaan Islam. Kata $a z a b$ dalam berbagai derivasinya disebut sebanyak 376 kali di Al-Qur'an (Belajar Bahasa Al-Quran, t.t). Oleh karena itu, kata azab menunjukkan suatu ajaran dalam agama Islam yang dimengerti oleh umat 


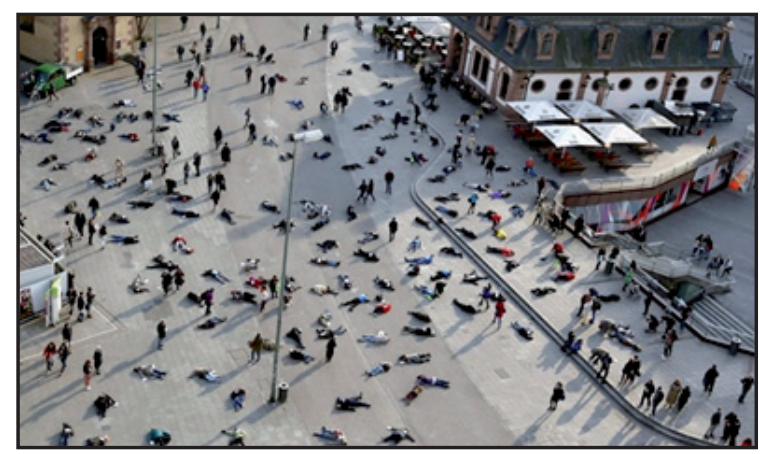

Sumber: Pfafenbach, K. (2014, 24 Maret).

Gambar 5. Seni Instalasi Flash Mob di Jerman

Islam. Berikutnya, sebagai penguat imajinasi khalayak pembaca bahwa $a z a b$ itu telah hadir di China maka diunggah foto (visual image) bagaimana kondisi banyak mayat bergelimpangan di jalanan, seperti terlihat pada Gambar 5 .

Kisah tragis yang dialami umat Islam sebagaimana terdapat dalam keterangan foto diceritakan kepada umat Islam lainnya. Kesamaan identitas antara objek cerita dan penerima cerita dianggap mampu mengungkit bela rasa dan akhirnya membenci China yang direpresentasikan dalam wacana sebagai pihak yang membuat kesengsaraan terhadap objek cerita. Penulisan "Azab untuk China komunis" merupakan bentuk penegas representasi yang dibangun dan menjadi prinsip-prinsip tuduhan bahwa China adalah negara yang berasaskan komunis antiagama selayaknya mendapatkan azab.

Wacana disinformasi dengan judul "seorang perwira Cina memukuli seorang muslim Ugyur karena memiliki salinan Alquran" telah diverifikasi oleh turnbackhoax.id. Wacana ini dipublikasi oleh akun Twitter "Tkwondo_T" dan "PesonaKisbet" yang melakukan pengaduan ke@turnbackhoax atas berita itu. Berita ini menampilkan video seorang tentara sedang melakukan pemukulan terhadap seseorang warga di dalam suatu ruangan. Video yang diunggah oleh akun "Tkwondo_T" berasal dari unggahan pemilik akun twitter "ferrymaitimu" dengan narasi bertuliskan "kalian kok tega seperti ini sih? Meski dia pelaku kriminal, tapi jangan lagi diperlakukanbegini@Puspen_TNI’. Berita ini kemudian diubah oleh akun "Tkwondo_T" dengan narasi berbahasa Inggris seperti pada Gambar 6 .

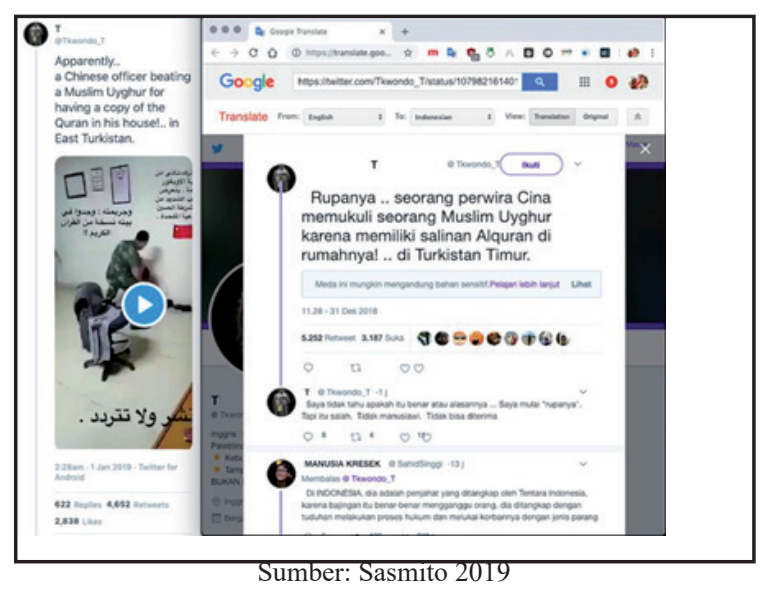

Gambar 6. Pemukulan Tentara Terhadap Muslim Uighur

Wacana disinformasi yang terdapat dalam Gambar 6 memiliki interseksi kontekstual. Selain itu, di Indonesia sendiri terdapat antagonisme terhadap komunisme, pemerintah China memang menciptakan dikotomi "kita vs muslim Uyghur" melalui retorika, kebijakan, dan praktik pembatasan pengetahuan secara khusus pendidikan Islam di Xinjiang (Mahmut, 2019) serta menerapkan deradikalisasi terhadap komunitas muslim Uyghur yang bertujuan untuk mengubah pola pikir mereka supaya tidak radikal (Zhou, 2019). Hal demikian dilakukan sebagai respon terhadap peristiwa 9/11 yang terjadi di Amerika. Interseksi ini menguatkan landasan representasi China sebagai negara yang anti-Islam sebagaimana tergambar dalam teks " $A$ Chinese officer beating a Muslim Uyghur having a copy of the Quran in the house". Tindakan ofensif dan koersif dilakukan oleh tentara China (beating) hanya disebabkan kepemilikan Al-Qur'an. Hal demikian menandakan bahwa memiliki Al-Qur'an dilarang di China karena membahayakan negara. Terlebih, perlakuan destruktif, seperti membakar Al-Qur'an sering dilakukan sebagai ekspresi antiIslam di berbagai negara. Komparasi peristiwaperistiwa serupa dapat membuat penerima segera mempercayai wacana disinformasi ini.

Gambar 7 pun menyajikan disinformasi mengenai tindakan destruktif terhadap AlQur'an. Sebagai penguatan fakta, telah dilakukan rekayasa visual yang membuat seolah-olah peristiwa itu terjadi di East Turkistan dengan memasukkan elemen tulisan berbahasa Arab dan ada bendera China. Penulisan "East Turkistan" 
merujuk pada suatu wilayah yang terkenal dengan nama pasukan teroris yaitu East Turkistan Movement (ETIM). Pemerintah China pernah menyampaikan klarifikasi secara resmi pada tahun 2002 bahwa telah terjadi serangan teroris yang dilakukan oleh ETIM pada tahun antara 1990 dan 2001 di Xinjiang yang mengakibatkan 162 kematian dan lebih 440 cedera (Information Office of State Council, 2002). Dengan ini East Turkistan menjadi wilayah berdarah hingga saat ini sebagai akibat adanya serangan teroris atau kegiatan deradikalisasi oleh pemerintah China.

Wacana judul "foto-foto pemusnahan Alquran, karpet dan segala sesuatu yang berkaitan dengan Islam di Turkestan Timur" telah diverifikasi oleh turnbackhoacx.id. Wacana ini diunggah pertama kali oleh akun Facebook "Yed Felistinesia" dengan memasukkan foto-foto dari beberapa sumber yang dijadikan satu kemudian diberi narasi (Gambar 7).

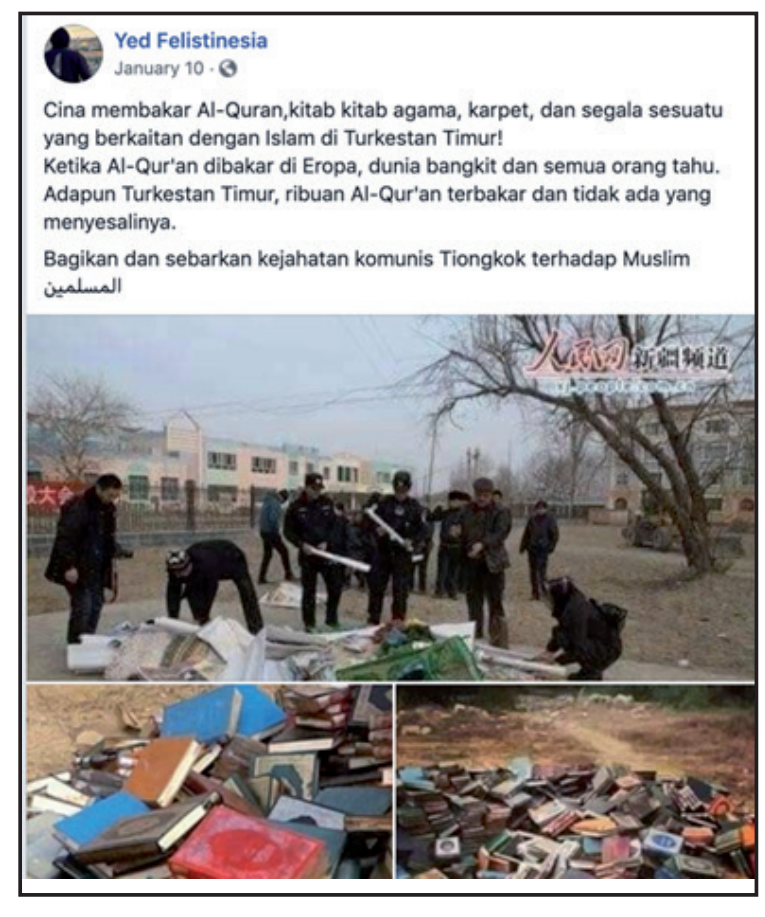

Sumber: Pfafenbach, K. (2014, 24 Maret).

Gambar 7. Pembakaran Kitab-Kitab Agama di Turkestan Timur.
Bila pada Gambar 6 komparasi peristiwa dekstruktif terhadap Al-Qur'an dapat terjadi pada level kontekstual, pada Gambar 7 ini komparasi terwujud dalam bentuk tekstual 'Ketika Alquran dibakar di Eropa dunia bangkit dan semua orang tahu. Adapun Turkestan Timur, ribuan Alquran terbakar dan tidak ada yang menyesalinya'. Kehadiran komparasi peristiwa ini mengarahkan penalaran bahwa perlakuan desktruktif terhadap Al-Qur'an merupakan wujud lazim sikap antiIslam dan sebagaimana respon umat Islam terhadap peristiwa-peristiwa terdahulu yang selalu bangkit melawan, perlakuan pemerintah China di Turkestan Timur pun harus direspon serupa. Secara retoris, wacana disampaikan secara negatif dengan tidak ada yang menyesali pembakaran itu untuk menunjukkan ironi di hadapan penerima. Dengan membuat ironi, peristiwa di Turkestan Timur diberi lampu sorot untuk menjadi peristiwa sentral.

Wacana disinformasi mengenai pembakaran Al-Qur'an di Turkestan Timur ini pun memberikan arahan tindakan masa depan yang harus dilakukan penerima, yakni 'bagikan dan sebarkan kejahatan komunis Tiongkok terhadap muslim'. Penyebutan secara eksplisit ini agar penerima langsung menafsirkan sebagaimana yang dikehendaki pembuat karena mampu mengurangi ketaksaan tindakan yang dimaksud pembuat dalam proses interpretasi penerima.

Tiga data disinformasi yang disajikan di atas semuanya diarahkan kepada China sebagai entitas negara. Tidak ada data yang ditampilkan yang secara eksplisit merujuk kepada etnis Cina di Indonesia. Namun, apakah yang membuat mereka terhubung? Stigma terhadap komunisme yang telah terbangun membuat apa-apa yang terarah ke China dalam sentimen komunisme bisa berdampak terhadap etnis Cina di Indonesia. Stigma yang dibangun dalam nalar konspiratif membuat relasi yang terbangun di antara keduanya seolah abstrak, bawah tanah, dan sukar dibuktikan. Meski bila dirujuk secara historis ke peristiwa 1965, menurut keterlibatan China dalam peristiwa itu sebatas mendukung dan mendorong Partai Komunis Indonesia untuk membentuk angkatan kelima, mengembangkan teknologi nuklir, dan memberikan perawatan medis untuk 
Soekarno dalam rangka memenangkan perang dingin, namun, tidak bisa dikatan China menjadi dalang dari peristiwa 1965 (Zhou, 2014).

Wacana disinformasi keagamaan di atas menguniversalisasikan sifat destruktif komunisme terhadap umat Islam. Universalisasi ini menihilkan peran agensi dan konteks. Siapa pun yang memercayai paham komunisme dan di mana pun seseorang tersebut berada, dia menjadi ancaman terhadap umat Islam, baik di Indonesia maupun di negeri lain. Dengan kata lain, sifat destruktif tersebut inheren dalam tubuh paham komunis. Pengetengahan strategi diskursif yang demikian mungkin dipengaruhi oleh trauma komunisme di Indonesia yang dinarasikan oleh Pemerintah Orde Baru dan/atau juga untuk membangkitkan trauma tersebut. Wacana disinformasi keagamaan seperti ini digunakan untuk mengubah keadaan perasaan, kepercayaan, pengetahuan, atau perilaku seseorang terhadap apa-apa dan siapa yang terhubung dengan komunisme maupun aktor pengusung komunis, dalam konteks data di atas adalah pemerintah China.

\section{PERAN DISINFORMASI KEAGAMAAN}

Tulisan ini mendasarkan pengertian disinformasi mengandung prinsip direktif, yaitu instrumentasi teks untuk membentuk suatu keadaan tertentu di masa pascainterpretasi teks. Penerima menjadi agensi yang menciptakan keadaan tersebut bila menginterpretasi teks sesuai arahan pembuat disinformasi. Definisi ini dihasilkan melalui elaborasi teoretis atas teori tindak tutur (Austin, 1968), analisis wacana kritis (Fairclough, 1989; 1992; 1995), teori pelintiran kebencian (George, 2017), serta definisi disinformasi dari Komisi Uni Eropa (2018).

Deskripsi mengenai exisiting narratives di atas pun menggambarkan bahwa penarasian keagamaan terkait erat dalam persaingan politik dan ekonomi. Oleh karena itu, dalam analisis mengenai wacana disinformasi bersentimen agama, perlu dilihat peran wacana tersebut dalam kontestasi persaingan kelompok Islam dengan komunisme di Indonesia. Meski komunisme sebagai ideologi politik formal tidak ada di Indonesia, namun eksistensinya tetap dinarasikan baik terarah kepada China yang kemudian terhubung secara konspiratif melalui penokohan Presiden Jokowi dan akhirnya kembali terelasi dengan etnis Cina atau disebarkan dan dioperasikan secara diam-diam sehingga memunculkan istilah 'Komunis Gaya Baru' dalam wacana politik Indonesia. Pola perujukan komunisme yang kedua pun akhirnya bermuara pada stigmatisasi etnis Cina di Indonesia.

Tulisan ini tidak mendefinisikan penggunaan komunisme dalam disinformasi keagamaan sebagai tindakan yang dilakukan oleh umat Islam sendiri, tetapi topik komunisme digunakan karena komunisme dalam perjalanan sejarahnya telah menjadi memoria passionis-emdash ingatan akan penderitaan bagi umat Islam. Kepiluan yang terasa dalam solidaritas sesama umat Islam dibangkitkan dan dirawat dengan menarasikan kekejaman komunisme yang membantai dan mengancam eksistensi umat Islam, seperti peristiwa historis 1948 dan 1965 atau perlakuan diskriminatif pemerintahan komunis China terhadap muslim di sana. Ingatan akan penderitaan ini membuat interpretasi umat Islam berpijakan pada rasa kengerian, kekhawatiran, dan kebencian. Hal demikian tergambar dalam data-data wacana yang ditampilkan dalam bagian existing narratives, terutama pada Gambar 6.

Secara proporsi demografi pun, pendudukan Indonesia yang beragama Islam berjumlah $87 \%$ dari total populasi 239,89 juta jiwa atau setara 209,12 jiwa sehingga memiliki potensi suara yang sangat besar. Oleh karena itu, disinformasi keagamaan seputar agama Islam dan komunisme ini berperan untuk merawat potensi suara persetujuan mayoritas yang selalu berada dalam kondisi 'siap pakai'. Dengan kata lain, umat Islam dipandang sebagai objek semata dalam proses kekuasaan di Indonesia. Disinformasi bersentimen agama Islam ini hendak menciptakan misinformasi di tingkat penerima sehingga mengambil keputusan hidup berdasarkan pertimbangan yang salah (Harsin, 2018). Keputusan hidup diambil bukan didasarkan pada pertimbangan informasional, melainkan aspek emosional, seperti rasa kekhawatiran atau hasrat untuk membalas dendam. 
Pengetengahan komunisme sebagai musuh mayoritas ini telah sukses mendasari pemerintahan Soeharto dalam mewujudkan rezim yang otoritarian. Penentangan rakyat terhadap kebijakan pembangunan dianggap sebagai wujud pembangkangan yang dilandasi infiltrasi komunisme. Wacana 'komunis bahaya laten' dihadirkan untuk mengokohkan keterlibatan cara militeristik dalam politik rezim Orde Baru. Selama penarasian komunisme dalam wacana politik Indonesia, selama itu pula potensi kembali otorianisme sebagai mode operasi kekuasaan politik terus ada. Wacana politik yang dibentuk untuk memobilisasi prasangka tidak mengandaikan diskusi argumentatif dalam penalarannya. Tipe wacana demikian hanya memantik subjektivitas primordial; informasi ditakar hanya berdasarkan keyakinan diri yang bersumber dari narasi identitas, seperti agama, etnis, atau kebangsaan.

Disinformasi bersentimen anti-China dan Cina ini diantagonismekan dengan Islam menjadi tema populis yang menyatukan Islamis militan yang konservatif dan nasionalis sayap kanan (Temby, 2019). Hal ini sebagaimana pernah dilakukan oleh dengan baik oleh pemerintahan Orde Baru yang mengetengahkan narasi antikomunisme untuk mewujudkan dominasi monolitik negara. Oleh karena itu, disinformasi sebagai manifestasi strategi politik pascakebenaran dapat menjadi pembentuk kondisi prootoritarinisme (Harsin, 2018). Kondisi otoritarian di Indonesia pascaSoeharto ini tidak melulu digubah oleh negara sebagaimana era Orde Baru, namun dapat pula sebagai dominasi mayoritas yang cenderung mendiskriminasi kelompok-kelompok minoritas.

\section{SIMPULAN}

Disinformasi keagamaan Islam di Indonesia mungkin memiliki daya persuasi tinggi karena memiliki landasan historis, dirawat oleh aktor otoritatif, dan ditopang oleh kondisi ketimpangan ekonomi antarkelompok masyarakat yang diasosiasikan secara aspek keagamaaan dan etnisitas. Daya persuasi ini dapat memantik keadaan mental penerima disinformasi terdominasi oleh kemarahan, kebencian, atau hasrat membalas dendam dalam menginterpretasi sebuah wacana.
Disinformasi ini pula dapat mengubah potensi sumber daya demografi menjadi sumber daya politik karena mampu menjangkau mayoritas penduduk Indonesia. Peristiwa Tanjung Balai memperlihatkan bahwa disinformasi ini pun sangat berpotensi mengalami ekskalasi dan memunculkan kerusuhan atau konflik antarkelompok masyarakat.

Memahami disinformasi dengan kacamata existing narratives yang menggambarkan keajegan tema dan relasi antagonisme membuat fenomena disinformasi tidak dapat dianggap fenomena individual semata tetapi juga merupakan sebuah fenomena kultural. Hal ini terlihat dari rekonstekstualisasi pengetahuan dan pengalaman kultural dari masa lalu. Hal ini pun menjelaskan mengapa cek fakta sebagai salah satu cara menanggulangi disinformasi digital menjadi kurang efisien begitu dihadapkan dengan persoalan kebenaran dan identitas. Cek fakta berpengaruh signifikan bila disinformasi/ misinformasi mengenai kelompok lawan dan menjadi kurang signifikan bila sebaliknya (Walter dkk., 2019). Kebenaran ditakar dalam timbangan identitas, bukan lagi faktualitas.

Keajegan tema dan antagonisme dalam existing narratives dapat menjawab mengapa suatu tema yang digunakan dalam disinformasi mampu membangkitkan amarah komunal karena kedua aspek itu telah ada dalam ingatan kultural. Kerusuhan di Wamena 2019 lalu yang dipicu oleh disinformasi berbentuk meme potret seorang guru nonorang asli Papua mengucapkan kata 'monyet'3 dapat menjadi contoh. Tema rasis 'monyet' dan aktor guru-aparatur negara-selaras dengan ingatan rasa sakit perlakuan rasis dalam bentuk pelabelan kebinatangan (monyet, babi, anjing) oleh otoritas formal (Hermawan, 2015).

Artikel ini menyisakan pertanyaan apakah yang berbahaya itu disinformasi sebagai disinformasi itu sendiri? Atau disinformasi mengenai hal tertentu di komunitas tertentu? Dalam hal yang pertama, disinformasi dapat

3 Salah Paham antara kata keras dan kera di kerusuhan Wamena, lihat https://nasional.tempo.co/read/1259380/ salah-paham-antara-kata-keras-dan-kera-di-kerusuhanwamena 
diibaratkan seperti api yang berkobar dan dapat membakar apapun, namun dalam hal yang kedua, disinformasi dapat diibaratkan sekadar menjadi percik api di atas tumpukan kayu kering yang berlumur bahan bakar. Jawaban atas pertanyaan ini menentukan penanganan disinformasi yang dikatakan membahayakan persatuan dan kesatuan Indonesia.

\section{DAFTAR PUSTAKA}

Austin, J. L. (1968). How to do things with words. Oxford University Press.

Europian Commission. (2018). A multi-dimensional approach to disinformation: Report of the independent High level Group on fake newsand online disinformation. https:/ec.europa.eu/ digital-single-market/en/news/final-reporthigh-level-expert-group-fake-news-and-onlinedisinformation

Fairclough, N. (1989). Language and power. Longman.inc.

Fairclough, N. (1992). Discourse and social changes. Polity Press.

Fairclough, N. (1995). Critical discourse analysis: The critical study of language. Longman.inc.

Febrylian, B. (2017, 20 November). [HOAX] "PKI dan CINA Sdh siap merampas Indonesia." Turnbackhoax.id. https://turnbackhoax.id/2017/11/20/ hoax-pki-dan-cina-sdh-siap-merampas-indonesia/

Belajar Bahasa Al-Quran, Metoda "Belajar Aktif Kata PerKata Lewat Intra/Internet.” (t.t.). http:// quran.bblm.go.id/

Farkas, J., \& Schou, J. (2018). Fake news as a floating signifier: Hegemony, antagonism and the politics of falsehood. Javnost, 25(3), 298-314. https://doi.org/10.1080/13183222.2018.14630 47

Harsin, J. (2018). Post-truth and critical communication studies. Dalam Oxford Research Encyclopedia of Communication (Issue April). https://doi. org/10.1093/acrefore/9780190228613.013.757

Mcgregor, K. (2009). A Reassessment of the significance of the 1948 Madiun Uprising to the Cold War in Indonesia. Kajian Malaysia, 27(1-2), 85-119.

Nadzir, I., Seftiani, S., \& Permana, Y. S. (2019). Hoax and misinformation in Indonesia: Insights from a nationwide survey. ISEAS Perspective, 92. https://www.iseas.edu.sg/images/pdf/ ISEAS_Perspective_2019_92.pdf

Poushter, Jacob \& Fetterolf, Janell. (2019). How people around the world view religion's role in their countries. dalam PEW Research Center. https:// www.pewresearch. org/global/2019/04/22/ how-people-around-the-world-view-religionsrole-in-their-countries/

Pfafenbach, K. (2014, 24 Maret). People lay down in a pedestrian zone as part of an art project in remembrance of the 528 victims of the Katzbach Nazi concentration camp, in Frankfurt, March 24, 2014 [Foto]. Reuters Pictures. https://pictures.reuters.com/archive/ GERMANY--BM2EA3O1B2X01.html

Ramaputra, S. (2020, 15 Januari). [SALAH] Foto-foto pemusnahan Al-qu'an, karpet dan segala sesuatu yang berkaitan dengan Islam di Turkestan Timur. Turnbackhoax.id. https://turnbackhoax. $\mathrm{id} / 2020 / 01 / 15 /$ salah-foto-foto-pemusnahanal-quan-karpet-dan-segala-sesuatu-yangberkaitan-dengan-islam-di-turkestan-timur/

Sasmito, A. (2020, 29 Januari). [SALAH] "Mayat orang Cina bergelimpangan di jalan kota Wuhan". Turnbackhoax.id. https://turnbackhoax.id/2020/01/29/salah-mayat-orang-cinabergelimpangan-di-jalan-kota-wuhan/

Sasmito, A. (2020, 29 Januari). [SALAH] "seorang perwira Cina memukuli seorang Muslim Uyghur karena memiliki salinan Alquran". Turnbackhoax.id. https://turnbackhoax. id/2019/01/02/salah-seorang-perwira-cinamemukuli-seorang-muslim-uyghur-karenamemiliki-salinan-alquran/

Temby, Q. (2019). Disinformation, violence, and anti-chinese sentiment in Indonesia's 2019 Elections. ISEAS Perspective, 67. https:// www.iseas.edu.sg/images/pdf/ISEAS_Perspective_2019_67.pdf

Temby, Q. B. H. (2020). The coronavirus infodemic in southeast asia: panic buying and mis-/ dis-information. FULCRUM ISEAS. https:// www.iseas.edu.sg/media/commentaries/ the-coronavirus-infodemic-in-southeast-asiapanic-buying-and-mis-dis-information/

Tim PBNU. 2013. Benturan NU-PKI 1948-1965. Jakarta: Pengurus Besar Nahdlatul Ulama.

Walter, N., Cohen, J., Holbert, R. L., \& Morag, Y. (2019). Fact-Checking : A meta-analysis of what works and for whom. Political Communication, 37(3), 350-375. https://doi.org/1 $0.1080 / 10584609.2019 .1668894$

Zhou, T. (2014). China and the Thirtieth Of September Movement. Number, 98, 29-58. https://doi. org/10.1353/ind.2014.0018

Zhou, Z. (2019). Chinese strategy for de-radicalization. Terrorism and Political Violence, 31(6), 1187-1209. 